\section{The Growth of the Tail in Urodele Larvae}

In amphibian larvae, the component parts of the tailbud are to be found in the neural plate stage as separate cell territories. The posterior tip of the prospective spinal cord lies in the neural plate at some distance before the blastopore. The material for the tail somites occupies the hind most part of the neural plate and continues into the invaginated chorda-mesoderm round the dorsal and the lateral blastoporal lips (BIJTEL and WoERDEMAN ${ }^{1}$, BIJTEL ${ }^{2}$, and others). By morphogenetic movements, these cell territories are brought together into the tailbud. As regards to the outgrowth of the tail-bud, some investigators have seen in the notochord the principal "motor" (PAsteels ${ }^{3}$, Dalco 4 ). Others, on the contrary, have concluded from their experiments that the elongation of the tail can take place independently of the notochord (DEVILLERS ${ }^{5}$, BYTINSKI-SALZ ${ }^{8}$ ).

The results of my own experiments, made in former years on urodele larvae, have given the the impression that the neural tube and the somites play the most active part, whereas the notochord functions as a splint. In recent years I have tried to complete the series of $\mathrm{my}$ experiments on larvae of Amblystoma mexicanum and Triton taeniatus. The results, which are briefly reported, here, have strengthened me in my conviction.

(1) If the hindpart of the neural plate containing the material for the tail neural tube and the tail somites is extirpated in the wide open neural plate stage, the tail either does not grow out at all or a small tail develops, dependent on the length of the part which has been extirpated and on its extension with regard to the blastopore (Fig. 1a)

(2) When the same part of the neural plate is grafted into the side of another larva, a tail-like structure develops from the graft. It has an axis formed by the neural tube surrounded by somites (Fig. 1 b).

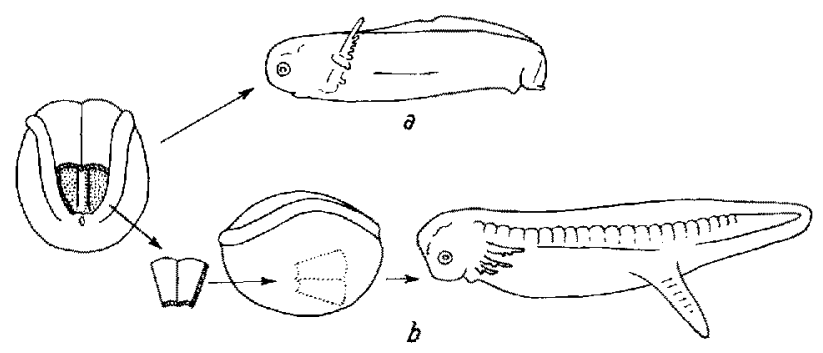

Fig. 1. Extirpation and transplantation of the hindpart of the neural plate containing tail neural tubc and tail somites. $a$ Donor; $b$ Host.

(3) When the tail notochord is extirpated in the neural plate stage, in the first stages of development the tail does not show many points of difference from the normal tail. In more advanced stages, however, it becomes evident that the tail cannot reach its normal length without a notochord (Fig. $2 a$ ).

(4) When the hindpart of the notochord is transplanted into the side of another larva, an irregular mass of

1 J. H. Brjtel and M. W. Woerdeman, Proc. roy. Acad. Sci. 31, 1030 (1928).

2 J. H. Bijtel, Roux'Arch. Entw,-Mech. 125, 448 (1951)

3 J. Pasteels, Ann. Soc. roy. zool. Belg. 70, 33 (1939).

4 A. Dalce, Loenf et son dynamisme organisateur (Ed. Albin Michel, Paris 1941).

5 C. Deviluers, C. r. Acad. Sci. Paris 227, 25, 1411 (1948).

6 H. Byrninski-Salz, C. r. $12^{e}$ Congres Int. Zool., Lisbonne 1985. notochord tissue develops. As a rule the piece of notochord develops into a coiled-up form (Fig, $2 b$ ).

(5) If the hindpart of the wide open neural plate containing the material for the tail neural tube and the tail somites is removed, rotated $180^{\circ}$ and re-implanted at the same spot, the direction of the outgrowing tail is determined by the direction in which the graft grows out.

(6) If, on the contrary, the tail notochord anlage is re-implanted after a rotation of $180^{\circ}$ in the same place, the tail grows out in the normal direction.

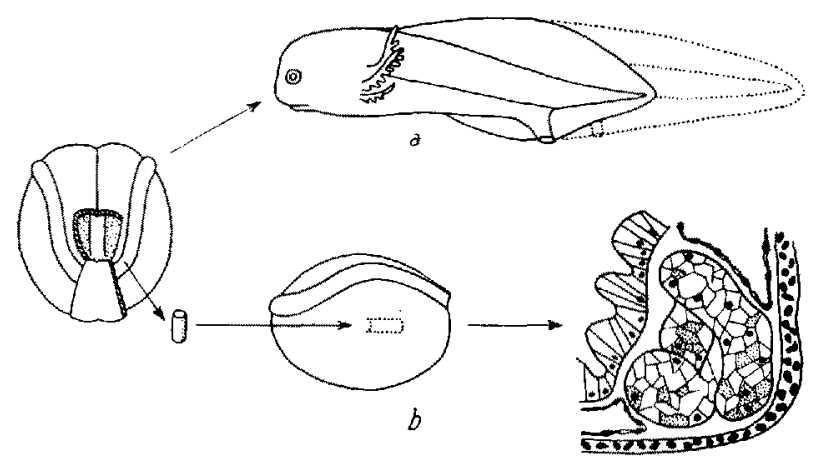

Fig. 2.-Extirpation and transplantation of the hindpart of the notochord. $a$ Donor; $b$ Hast.

From the results of these experiments it becomes clear that the first outgrowth of the tail is brought about by the outgrowth of the material for the neural tube and of that for the somites. The muscle cells of the developing myotomes have in themselves an autonomous stretching potency. Moreover, it is the combination of the neural and the mesodermal tissues which determines, in the first instance, in which direction the tail grows out. These two tissues, however, require an axis, a sort of splint, to retain the obtained length. In very early stages, the neural tube can play this part, but later on the notochord is necessary to take over this rôle. The notochord has in itself a potency for expansion, but its stretched form is moulded with the help of the surrounding tissues, especially with that of the somites.

J. Hubertha Bijtel.

Depariment of Anatomy and Embryology of the State University of Groningen, The Netherlands, February 29, 1956.

\section{Zusammenfassung}

Aus den Resultaten der Versuche an Urodelenlarven folgt, dass die Entwicklung des Schwanzneuralrohrs und der Schwanzsomiten das Auswachsen des Schwanzes hervorruft. Die zwei genannten Gewebe brauchen eine Art Schiene, um die erworbene Länge zu behalten. In den ersten Stadien der Schwanzentwicklung kann das Schwanzneuralrohr als Schiene dienen, später aber ist die Anwesenheit der Chorda notwendig, um diese Rolle zu übernehmen. Die sich entwickelnde Chorda hat zwar eine Fähigkeit zur Expansion, aber ihre gestreckte Form wird modelliert mit Hilfe der sie umgebenden Gewebe, besonders der Somiten. Die Richtung, in welcher der Schwanz auswächst, wird nicht durch die Chorda bestimmt, sondern durch die Kombination von Schwanzneuralrohr und Schwanzsomiten. 